\title{
Honey Dressing vs. Povidone Iodine Dressing
}

\author{
Sim Sai Tin • Viroj Wiwanitkit
}

Received: 9 September 2014 / Accepted: 7 November 2014 / Published online: 16 November 2014

(C) Association of Surgeons of India 2014

Dear editor, we would like to discuss on the publication on "Honey Dressing vs. Povidone Iodine Dressing [1]." Gulati et al. concluded that "Honey dressing is highly effective in achieving healing in chronic wounds as compared to Povidone iodine dressing [1]." In fact, the usefulness of honey in wound care is acceptable and honey is widely used. It is approved for the antibacterial activity and proposed to be a good therapeutic agent for infectious diseases [2]. However, the important consideration is the possible contamination of honey. Honey is reported for high contamination by Clostridium pathogen that can cause botulism [3]. To use honey in surgery, good preparation and sanitation control is needed.

\section{References}

1. Gulati S, Qureshi A, Srivastava A, Kataria K, Kumar P, Ji AB (2014) A Prospective Randomized Study to Compare the Effectiveness of Honey Dressing vs. Povidone Iodine Dressing in Chronic Wound Healing. Indian J Surg 76(3): 193-198

2. Yassin NA (2013) Honey as therapeutic agent for infectious diseases. Diag Ther Stud 2(3):43-50

3. de Centorbi OP, Satorres SE, Alcaraz LE, Centorbi HJ, Fernández R (1997) Detection of Clostridium botulinum spores in honey. Rev Argent Microbiol 29(3):147-151

S. S. Tin $(\bowtie)$

Medical Center, Shantou, China

e-mail: simsaitin@gmail.com

V. Wiwanitkit

Hainan Medical University, Haikou, China 